\title{
3. EARLY DIAGENESIS AND THE ORIGIN OF DIAGENETIC CARBONATE IN SEDIMENT RECOVERED FROM THE ARGO BASIN, NORTHEASTERN INDIAN OCEAN (SITE 765) ${ }^{1}$
}

\author{
John S. Compton ${ }^{2}$
}

\begin{abstract}
Degradation of organic matter in slightly organic-rich (1 wt\% organic carbon) Neogene calcareous turbidites of the Argo Basin at Site 765 by sulfate reduction results in pore-water phosphate, ammonium, manganese, and carbonate alkalinity maxima. Pore-water calcium and magnesium decrease in the uppermost 100 meters below seafloor (mbsf) in response to the precipitation of calcian dolomite with an average composition of $\mathrm{Ca}_{1.15} \mathrm{Mg}_{0.83} \mathrm{Fe}_{0.02}\left(\mathrm{CO}_{3}\right)_{2}$. Clear, euhedral dolomite rhombs range from $<1$ to $40 \mu \mathrm{m}$ in diameter and occur in trace to minor amounts $(<1-2 \mathrm{wt} \%)$ in Pleistocene to Pliocene sediment $(62-210 \mathrm{mbsf})$. The abundance of dolomite increases markedly $(2-10 \mathrm{wt} \%)$ in Miocene sediment $(210-440 \mathrm{mbsf})$. The dolomite is associated with diagenetic sepiolite and palygorskite, as well as redeposited biogenic low-Mg calcite and aragonitic benthic foraminifers. Currently, dolomite is precipitating at depth within the pore spaces of the sediment, largely as a result of aragonite dissolution. The rate of aragonite dissolution, calculated from the pore-water strontium profile, is sufficient to explain the amount of dolomite observed at Site 765. A foraminiferal aragonite precursor is further supported by the carbon and oxygen isotopic compositions of the dolomite, which are fairly close to the range of isotopic compositions observed for Miocene benthic foraminifers. Dolomite precipitation is promoted by the degradation of organic matter by sulfate-reducing bacteria because the lower pore-water sulfate concentration reduces the effect of sulfate inhibition on the dolomite reaction and because the higher carbonate alkalinity increases the degree of saturation of the pore waters with dolomite. Organic matter degradation also results in the precipitation of pyrite and trace amounts of apatite (francolite), and the release of iron and manganese to the pore water by reduction of $\mathrm{Fe}$ and $\mathrm{Mn}$ oxides.

Spherical, silt-sized aggregates of microcrystalline calcian rhodochrosite occur in trace to minor amounts in Lower Cretaceous sediment from 740 to $900 \mathrm{mbsf}$ at Site 765. A negative carbon isotopic composition suggests that the rhodochrosite formed early in the sulfate reduction zone, but a depleted oxygen isotopic composition suggests that the rhodochrosite may have recrystallized at deeper burial depths.
\end{abstract}

\section{INTRODUCTION}

Diagenetic carbonate minerals are commonly observed in marine sediments in minor to trace amounts (Lumsden, 1988). Most of the diagenetic carbonate observed at DSDP sites has been reported as dolomite. Although some marine dolomites are detrital or reworked from shallow water environments, many are authigenic. For example, dolomite currently is precipitating at depth in the sediment of a number of organic-rich hemipelagic DSDP sites (Pisciotto and Mahoney, 1981; Kelts and McKenzie, 1982; Baker and Burns, 1985). In addition to dolomite, early diagenesis of organic-rich marine sediment can result in the precipitation of the authigenic minerals pyrite and francolite (carbonate fluorapatite), as observed, for example, in the Miocene Monterey Formation (Kastner et al., 1984; Compton, 1988a). Dolomite can form by replacement of precursor carbonate or by direct precipitation from supersaturated pore water. Pore waters can become highly supersaturated with respect to diagenetic carbonate minerals from the increase in carbonate alkalinity that results from the bacterial degradation of organic matter (Compton, $1988 \mathrm{~b}) . \mathrm{Mg}$, and some of the $\mathrm{Ca}$, required during dolomite precipitation are supplied by diffusion from the overlying seawater (Baker and Burns, 1985; Compton and Siever, 1986). The mineralogy of the diagenetic carbonate that precipitates will depend largely on the composition of the pore water. Dolomite is a common diagenetic carbonate in marine sediments, in part because $\mathrm{Mg}$ is abundant in seawater. However, $\mathrm{Ca}, \mathrm{Fe}$, and $\mathrm{Mn}$

\footnotetext{
${ }^{1}$ Gradstein, F. M., Ludden, J. N., et al., 1992. Proc. ODP, Sci, Results, 123: College Station, TX (Ocean Drilling Program).

${ }^{2}$ Department of Marine Science, University of South Florida, St. Petersburg, FL 33701, U.S.A.
}

carbonates can precipitate instead of dolomite. For example, calcite concretions have been reported from organic-rich Devonian shales (Dix and Mullins, 1987), and rhodochrosite has been reported from organic-rich sediment from the Baltic Sea (Jakobsen and Postma, 1989) and from the Franciscan Complex, California (Hein and Koski, 1987).

Significant amounts of diagenetic carbonate are less common in pelagic sediments because they generally have lower sedimentation rates and lower organic carbon contents in comparison to hemipelagic sediments. The occurrence of relatively large amounts of dolomite in sediment recovered from the Argo Basin thus was surprising because the basin floor lies below the carbonate compensation depth (CCD) at a water depth of $5740 \mathrm{~m}$, and the sediment is only slightly organic-rich, with an average of about $1 \mathrm{wt} \%$ organic carbon in the uppermost $100 \mathrm{mbsf}$ (Ludden, Gradstein, et al., 1990). In this study, I discuss early diagenesis at Site 765 and the origin of its diagenetic dolomite and rhodochrosite.

\section{METHODS}

Squeezed pore-water samples were analyzed on board the JOIDES Resolution using standard techniques (Ludden, Gradstein, et al., 1990). Pore-water Sr and $\mathrm{K}$ were analyzed using flame atomic absorption spectroscopy at the University of South Florida (USF). Sediment samples were collected on board the ship. Bulk sediment samples were separated into $>38-, 2-$ to $38-$, and $<2-\mu \mathrm{m}$ size fractions by sieving and centrifuging. X-ray diffraction (XRD) analysis was performed using $\mathrm{Cu} \mathrm{K} \alpha$ radiation on the Philips XRD unit on board the ship and on the Scintag XDS 2000 unit at USF. Relative abundance of the carbonate minerals was estimated from the intensity (integrated area) of the carbonate mineral XRD peaks. The dolomite was separated from the biogenic carbonate by suspending the 2 - to $38-\mu \mathrm{m}$ size fraction in 
dispersant and then ultrasonicating it. The settled silt-sized fraction was repeatedly treated at room temperature with a sodium acetate-acetic acid buffer at pH 5 (Jackson, 1969) until calcite and aragonite were no longer detectable by XRD $(<0.5 \mathrm{wt} \%)$. The dolomite underwent only minor dissolution as a result of this treatment (Pl. 1, Fig. 1).

The stable carbon and oxygen isotopic compositions of the diagenetic carbonate were measured using a Finnigan-MAT 251 mass spectrometer in the laboratory of P. Swart at the Rosenstiel School of Marine and Atmospheric Sciences, University of Miami. Scanning electron microscopy (SEM) was performed on an ISI-DSI3O SEM at USF. The elemental composition of individual dolomite rhombs was qualitatively determined using a Kevex EDX attachment during SEM analysis. Quantitative elemental analysis of the diagenetic carbonate was determined using direct current plasma emission spectrometry (DCP) by T. Plank at the Lamont-Doherty Geological Observatory, Columbia University.

\section{CARBONATE MINERALOGY}

Neogene sediment at Site 765 contains highly variable but generally large amounts of carbonate relative to the underlying Cretaceous sediment (Fig. 1). The carbonate content is particularly high and averages $70 \mathrm{wt} \%$ in Neogene sediment from 200 to 400 mbsf. These Neogene carbonate sediments have been interpreted as having been deposited as turbidites shed off of the adjacent Australian continental margin (Ludden, Gradstein, et al., 1990). The turbidite units have variable thickness and typically consist of a basal foraminiferal sand, an overlying nannofossil ooze, and an upper clay layer that contains only minor to trace amounts of carbonate. Carbonate minerals identified at Site 765 include calcite, aragonite, dolomite, and minor amounts of rhodochrosite and siderite. No high-Mg calcite was observed. Low-Mg calcite is the dominant carbonate mineral and occurs as nannofossils, foraminifers, and recrystallized aggregates (PI. 1, Fig. 4). Calcitic calcispheres were observed in several places in the basal, Lower Cretaceous sediment.

Aragonite occurs as benthic foraminifers that originally inhabited water depths of less than $2000 \mathrm{~m}$ (Ludden, Gradstein, et al., 1990). The aragonite content is proportional to the amount of $\mathrm{Sr}$ in the bulk sediment (Fig. 1) because most of the $\mathrm{Sr}$ occurs in aragonite. The Sr content of the bulk sediment (Ludden, Gradstein, et al., 1990) indicates that aragonite is most abundant in sediment from 200 to $440 \mathrm{mbsf}$ and agrees with the aragonite abundance estimated by XRD (Fig. 1). No aragonite was detected in sediment older than the Neogene (below $450 \mathrm{mbsf}$ ); however, some aragonite may be present at $510 \mathrm{mbsf}$ because of the elevated $\mathrm{Sr}$ content of the bulk sediment at this depth. The fairly abrupt increase in the aragonite content in the transition from Paleogene to Neogene sediment at Site 765 corresponds to an order-of-magnitude increase in the sedimentation rate (Ludden, Gradstein, et al., 1990). Aragonitic foraminifers are concentrated in the basal foraminiferal sand layers of the turbidite beds. Long, prismatic crystals, observed in the SEM, are thought to represent the tests of aragonitic foraminifers that have undergone extensive solution (Pl. 1, Fig. 3).

Diagenetic carbonate at Site 765 occurs as disseminated, siltsized rhombohedral crystals. These rhombic crystals were originally thought to be ankerite because of the larger d-spacing of the 104 reflection and the presence of an iron peak in the SEM EDX analyses. Quantitative elemental analyses by DCP later revealed that the carbonate rhombs are calcium-rich dolomite that contains

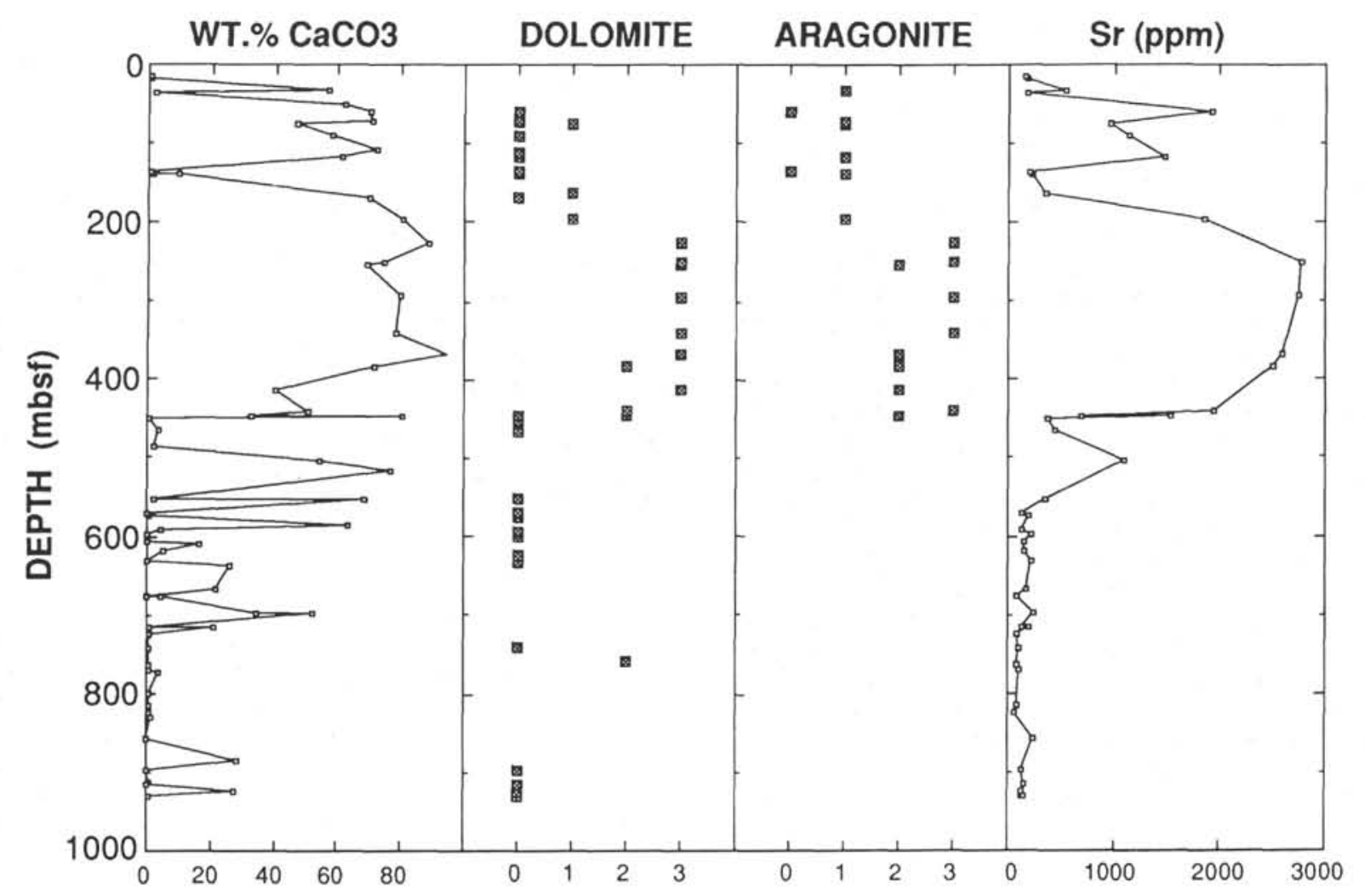

Figure 1. Weight percent total carbonate, relative abundance of dolomite and aragonite from the XRD patterns $(0=$ trace, $4=$ abundant $)$, and the $\mathrm{Sr}$ content of the bulk sediment as a function of sediment depth at Site 765. Weight percent carbonate and $\mathrm{Sr}$ content of the bulk sediment from Ludden, Gradstein, et al. (1990). 
an average of only several weight percent iron (Table 1). The dolomite-ankerite solid-solution series of natural samples exists from $100 \%$ dolomite to about $30 \%$ dolomite $-70 \%$ ankerite; the ideal ankerite end-member, $\mathrm{CaFe}\left(\mathrm{CO}_{3}\right)_{2}$, is not known to exist in nature, nor has it been synthesized in the laboratory (Essene, 1983). Distinguishing between dolomite and ankerite is difficult in the light microscope because both carbonate minerals commonly occur as clear, rhombic crystals. In addition, the distinction between calcian dolomite and ankerite can be difficult using routine bulk sediment XRD analysis of samples containing minor amounts of these carbonate minerals because the d-spacing of their most intense reflection (104) is similar $(0.290 \mathrm{~nm}$ for ankerite and calcian dolomite, compared to $0.288 \mathrm{~nm}$ for near-ideal dolomite). Therefore, elemental analysis is necessary to distinguish between calcian dolomite and ankerite.

The dolomite occurs in the coarse clay to silt size fraction as euhedral, clear, rhombohedral crystals that range in size from $<1$ to $40 \mu \mathrm{m}$ in diameter (Pl. 1, Fig. 1; Pl. 2, Figs. 1, 2, and 3). Dolomite rhombs were observed first in Pleistocene foraminiferal sand at $62 \mathrm{mbsf}$. Trace $(<1 \mathrm{wt} \%)$ to minor (1-2wt\%) amounts of dolomite occur from 62 to 210 mbsf. The dolomite content of the sediment increases to approximately 2 to $10 \mathrm{wt} \%$ in Miocene sediment from 210 to $441 \mathrm{mbsf}$. This marked increase in dolomite from 210 to 441 mbsf corresponds to a carbonate-rich, Miocene sediment interval that contains abundant low- $\mathrm{Mg}$ calcite, aragonite, and Mg-rich clay minerals (Fig. 1). The dolomite appears to have grown in the pore spaces of the sediment, forming clear, euhedral single crystals or clusters of intergrown crystals (PI. 2). Crystal faces are not pitted or etched and suggest that the dolomite is in equilibrium with the pore water (etched faces in Pl. 1, Fig. 1 are a result of sample processing). Dolomite rhombs were observed in the SEM to be intimately associated with the fibrous $\mathrm{Mg}$-rich silicates sepiolite and palygorskite (Pl. 2, Figs. 1, 2, and 3 ). In some samples, the fibrous clay minerals drape over the surface of the dolomite crystals, and in other samples, clay minerals appear to be encased in the dolomite. The sepiolite and palygorskite, as well as a mixed-layered illite/smectite/chlorite, at Site 765 are believed to be authigenic and to have formed during dolomite precipitation (Compton and Locker, this volume). Minor to trace amounts of dolomite also were found in sediment below 485 mbsf. Trace amounts of siderite were tentatively identified in several samples from 525 to $631 \mathrm{mbsf}$, while calcian rhodochrosite occurs in places as silt-sized microcrystalline nodules in Lower Cretaceous sediment from 740 to 900 mbsf.
The texture of the dolomite described above and its intimate association with delicate authigenic clay minerals demonstrate that the dolomite at Site 765 is not detrital. If the dolomite were detrital or had formed on the Australian continental margin and had been redeposited in the Argo Basin by turbidity currents, then the more dense, silt-sized dolomite rhombs would be expected to have settled preferentially at the base of the turbidites. And yet, the abundance of dolomite does not correspond to the sample position within the turbidite units; silt-sized dolomite rhombs not only occur in the basal foraminiferal sands, but are also present in the overlying nannofossil ooze and clayey tops of the turbidite units. In addition, comparable amounts of dolomite were not detected at adjacent sites along the northwestern Australia continental margin, except at DSDP Site 262 in the Timor Trough, where high-salinity, aragonite-rich, Pliocene sediment contains abundant calcian dolomite (Veevers, Heirtzler, et al., 1974; Cooks et al., 1974).

\section{EARLY DIAGENESIS}

Pore waters from Neogene sediments recovered from Site 765 exhibit an exponential decrease in sulfate-ion concentration typical of marine sediment undergoing organic matter degradation by sulfate-reducing bacteria (Claypool and Kaplan, 1974; Gieskes, 1983). An asymptotic sulfate concentration of about $7 \mathrm{mM}$ is attained by 254 mbsf (Table 2; Fig. 2). The organic carbon content decreases rapidly from about $1 \mathrm{wt} \%$ in the uppermost sediment to less than 0.5 wt $\%$ by 100 mbsf (Ludden, Gradstein, et al., 1990). The relatively low organic carbon content at Site 765 suggests that sufficient organic carbon is not available to drive the sulfate concentration to near zero, as commonly observed in more organic-rich marine sediments (Gieskes, 1981, 1983). Sulfate reduction results in an increase in pore-water phosphate, ammonium, and carbonate alkalinity (Table 2; Fig. 2). Although pore-water $\mathrm{H}_{2} \mathrm{~S}$ was not measured at Site 765 , sulfate reduction usually increases the total dissolved $\mathrm{H}_{2} \mathrm{~S}$ (e.g., Devol et al., 1984). The rapid increase in pore-water phosphate, sulfide, and carbonate alkalinity can lead to the precipitation of diagenetic phosphate, sulfide, and carbonate minerals (Fig. 3).

Phosphate ion exhibits two maxima at 14 and $72 \mathrm{mbsf}$ and then decreases rapidly to near-zero at a depth that corresponds to the sulfate asymptotic value (Fig. 2). Cemented carbonate nodules from 52 mbsf (Sample 123-765B-6H-3, 145-150 cm) were found to contain the mineral francolite, a carbonate fluorapatite, $\mathrm{Ca}_{5}\left(\mathrm{PO}_{4}, \mathrm{CO}_{3}\right)_{3}(\mathrm{~F})$. This francolite may have formed by replace-

Table 1. Elemental and isotopic compositions of diagenetic carbonate from Site 765.

\begin{tabular}{|c|c|c|c|c|c|c|c|c|c|c|}
\hline $\begin{array}{l}\text { Core, section, } \\
\text { interval }(\mathrm{cm})\end{array}$ & Mineralogy & $\begin{array}{l}\text { Depth } \\
\text { (mbsf) }\end{array}$ & $\begin{array}{l}\mathrm{CaCO}_{3} \\
(\mathrm{~mol} \%)\end{array}$ & $\begin{array}{l}\mathrm{MgCO}_{3} \\
(\mathrm{~mol} \%)\end{array}$ & $\begin{array}{l}\mathrm{FeCO}_{3} \\
(\mathrm{~mol} \%)\end{array}$ & $\begin{array}{l}\mathrm{MnCO}_{3} \\
(\mathrm{~mol} \%)\end{array}$ & $\begin{array}{c}\mathrm{Sr} \\
(\mathrm{ppm})\end{array}$ & $\underset{(\mathrm{ppm})}{\mathrm{Ba}}$ & $\begin{array}{l}\delta^{13} \mathrm{C} \\
(960)\end{array}$ & $\begin{array}{l}\delta^{18} \mathrm{C} \\
(\% 0)\end{array}$ \\
\hline \multicolumn{11}{|l|}{ 123-765B- } \\
\hline $8 \mathrm{H}-3,145-150$ & Dolomite & 71.6 & & & & & & & 3.15 & 4.12 \\
\hline $12 \mathrm{H}-3,145-150$ & Dolomite & 110.1 & & & & & & & 3.74 & 5.49 \\
\hline $15 \mathrm{H}-3,145-150$ & Dolomite & 139.0 & & & & & & & 6.62 & 5.51 \\
\hline $18 \mathrm{H}-3,145-150$ & Dolomite & 168.1 & & & & & & & -0.11 & 4.44 \\
\hline $24 \mathrm{X}-3,145-150$ & Dolomite & 226.3 & 57.6 & 41.6 & 0.8 & 0.0 & 520 & 18 & 1.66 & 4.66 \\
\hline $27 \mathrm{X}-2,145-150$ & Dolomite & 253.9 & 56.6 & 42.1 & 1.2 & 0.0 & 165 & 16 & 2.08 & 4.05 \\
\hline $31 X-3,140-150$ & Dolomite & 294.1 & 57.8 & 41.7 & 0.6 & 0.0 & 554 & 65 & 1.52 & 4.90 \\
\hline $36 \mathrm{X}-2,140-150$ & Dolomite & 340.9 & 58.6 & 40.6 & 0.8 & 0.0 & 663 & 68 & 2.32 & 5.38 \\
\hline $39 \mathrm{X}-1,66-91$ & Dolomite & 367.6 & & & & & & & 2.14 & 5.10 \\
\hline \multicolumn{11}{|l|}{$123-765 \mathrm{C}$ - } \\
\hline $4 \mathrm{R}-3,140-150$ & Dolomite & 383.5 & 57.5 & 40.8 & 1.6 & 0.1 & 711 & 77 & 1.88 & 4.90 \\
\hline $7 \mathrm{R}-4,75-85$ & Dolomite & 413.3 & 56.4 & 40.9 & 2.4 & 0.3 & 476 & 4 & 0.63 & 2.61 \\
\hline $10 \mathrm{R}-3,140-150$ & Dolomite & 441.0 & & & & & & & 2.40 & 3.71 \\
\hline $45 \mathrm{R}-3,145-150$ & Rhodochrosite & 772.7 & 11.5 & 3.8 & 1.0 & 83.7 & 32 & 0 & -7.97 & 0.73 \\
\hline
\end{tabular}


Table 2. Pore water composition, Site $\mathbf{7 6 5 .}$

\begin{tabular}{|c|c|c|c|c|c|c|c|c|c|c|c|}
\hline $\begin{array}{l}\text { Core, section, } \\
\text { interval }(\mathrm{cm})\end{array}$ & $\begin{array}{l}\text { Depth } \\
\text { (mbsf) }\end{array}$ & $\mathrm{pH}$ & $\begin{array}{c}\text { Alk } \\
(\mathrm{mM})\end{array}$ & $\underset{(\mathrm{mM})}{\mathrm{Mg}}$ & $\underset{(\mathrm{mM})}{\mathrm{Ca}}$ & $\mathrm{Mg} / \mathrm{Ca}$ & $\underset{(\mathrm{mM})}{\mathrm{SO}_{4}}$ & $\begin{array}{l}\mathrm{PO}_{4} \\
(\mu \mathrm{M})\end{array}$ & $\begin{array}{c}\mathrm{NH}_{4} \\
(\mathrm{mM})\end{array}$ & $\begin{array}{c}\mathrm{Mn} \\
(\mu \mathrm{M})\end{array}$ & $\underset{(\mathrm{mM})}{\mathrm{Sr}}$ \\
\hline \multicolumn{12}{|l|}{$123-765 \mathrm{~A}-$} \\
\hline $1 \mathrm{H}-1,53-56$ & 0.5 & 8.0 & 3.94 & 51.9 & 10.1 & 5.1 & 27.7 & 4.8 & 0.2 & 43.7 & 0.12 \\
\hline $1 \mathrm{H}-3,145-150$ & 4.5 & 7.6 & 5.52 & 51.5 & 10.3 & 5.0 & 25.3 & 4.2 & 0.3 & 34.4 & 0.15 \\
\hline $1 \mathrm{H}-1,147-150$ & 1.5 & 7.3 & 4.35 & 51.6 & 10.5 & 4.9 & 26.4 & 4.4 & 0.2 & 57.1 & 0.12 \\
\hline $2 \mathrm{H}-3,145-150$ & 13.8 & 7.8 & 7.50 & 50.9 & 10.2 & 5.0 & 23.1 & 14.0 & 0.5 & 72.7 & 0.16 \\
\hline $3 \mathrm{H}-3,145-150$ & 23.3 & 7.8 & 8.14 & 50.6 & 9.7 & 5.2 & 21.6 & 11.6 & 0.7 & 50.9 & 0.17 \\
\hline $4 \mathrm{H}-3,145-150$ & 33.0 & 7.8 & 6.96 & 50.6 & 8.3 & 6.1 & 20.1 & 7.9 & 0.6 & 23.1 & 0.19 \\
\hline $5 \mathrm{H}-3,145-150$ & 42.6 & 7.6 & 7.53 & 50.2 & 7.8 & 6.5 & 19.9 & 6.4 & 0.6 & 21.3 & 0.20 \\
\hline $6 \mathrm{H}-3,145-150$ & 52.3 & 7.5 & 8.13 & 49.8 & 7.4 & 6.8 & 18.7 & 6.9 & 0.8 & 20.7 & 0.23 \\
\hline $7 \mathrm{H}-3,145-150$ & 61.9 & 7.5 & 8.64 & 48.8 & 7.2 & 6.8 & 16.7 & 7.7 & 1.0 & 8.3 & 0.28 \\
\hline $8 \mathrm{H}-3,145-150$ & 71.6 & 7.5 & 9.13 & 48.6 & 7.1 & 6.9 & 15.6 & 9.8 & 0.8 & 4.0 & 0.31 \\
\hline $9 \mathrm{H}-3,145-150$ & 81.3 & 7.5 & 8.63 & 47.9 & 6.7 & 7.2 & 14.5 & 7.7 & 0.9 & 3.3 & 0.33 \\
\hline $10 \mathrm{H}-3,145-150$ & 90.9 & 7.6 & 7.55 & 46.3 & 6.0 & 7.7 & 13.5 & 6.4 & 0.9 & 4.4 & 0.37 \\
\hline $12 \mathrm{H}-3,145-150$ & 110.1 & 7.7 & 5.40 & 44.0 & 5.5 & 8.0 & 12.5 & 1.4 & 1.0 & 6.9 & 0.42 \\
\hline $15 \mathrm{H}-3,145-150$ & 139.0 & 7.7 & 3.84 & 39.5 & 6.7 & 5.9 & 10.6 & 0.9 & 1.0 & 3.8 & 0.64 \\
\hline $18 \mathrm{H}-3,145-150$ & 168.1 & 7.6 & 2.99 & 35.8 & 8.1 & 4.4 & 10.0 & 0.6 & 1.1 & 3.4 & 0.87 \\
\hline $21 X-2,145-150$ & 195.7 & 7.6 & 2.48 & 32.7 & 10.4 & 3.2 & 9.1 & 1.1 & 1.2 & 0.5 & 1.11 \\
\hline $24 X-3,145-150$ & 226.3 & 7.8 & 2.78 & 31.3 & 11.5 & 2.7 & 9.0 & 0.5 & 1.6 & 0.5 & 1.41 \\
\hline $27 \times-2,145-150$ & 253.9 & 7.6 & 2.27 & 29.3 & 11.3 & 2.6 & 7.6 & 0.9 & 1.6 & 0.5 & 1.62 \\
\hline $31 X-3,140-150$ & 294.1 & 7.7 & 2.30 & 28.7 & 12.0 & 2.4 & 7.1 & 0.9 & 1.7 & 0.5 & 1.89 \\
\hline $36 \mathrm{X}-2,140-150$ & 340.9 & 7.8 & 2.48 & 28.2 & 13.4 & 2.1 & 8.0 & 0.0 & 2.0 & 0.8 & 2.09 \\
\hline $39 X-1,86-91$ & 367.6 & 7.4 & 2.71 & 26.5 & 14.4 & 1.8 & 6.0 & 0.5 & 1.9 & 0.5 & 1.79 \\
\hline \multicolumn{12}{|l|}{$123-765 \mathrm{C}$ - } \\
\hline $4 \mathrm{R}-3,140-150$ & 383.5 & 7.5 & 1.89 & 31.4 & 12.5 & 2.5 & 7.8 & 0.0 & 1.5 & & 1.82 \\
\hline $7 R-4,75-85$ & 413.3 & 7.5 & 0.81 & 31.6 & 13.3 & 2.4 & 8.0 & 0.0 & 1.4 & 2.7 & 1.71 \\
\hline $10 \mathrm{R}-3,140-150$ & 441.0 & 7.4 & 1.57 & 31.4 & 13.4 & 2.3 & 8.0 & 0.0 & 1.6 & 2.7 & 1.47 \\
\hline $15 \mathrm{R}-1,115-125$ & 484.9 & 7.9 & 2.57 & 40.0 & 18.3 & 2.2 & 16.6 & 0.0 & 1.0 & & 1.00 \\
\hline $18 \mathrm{R}-3,140-150$ & 516.4 & 7.5 & 3.56 & 35.4 & 20.0 & 1.8 & 9.8 & 0.0 & 0.8 & 18.0 & 0.68 \\
\hline $22 \mathrm{R}-2,140-150$ & 553.1 & 7.3 & 3.03 & 34.1 & 23.9 & 1.4 & 12.4 & & 0.9 & & 0.48 \\
\hline $25 \mathrm{R}-4,140-150$ & 585.0 & 7.1 & & 36.8 & 25.8 & 1.4 & 15.4 & & 0.6 & & 0.37 \\
\hline $28 \mathrm{R}-2,140-150$ & 610.0 & 7.2 & & 36.1 & 30.0 & 1.2 & 13.6 & & 0.9 & & 0.37 \\
\hline $31 \mathrm{R}-2,130-140$ & 638.2 & 7.3 & & 35.3 & 31.4 & 1.1 & 14.6 & & 0.6 & & 0.29 \\
\hline $34 \mathrm{R}-3,115-125$ & 668.6 & 7.2 & & 32.0 & 33.2 & 1.0 & 16.0 & & 0.6 & & 0.28 \\
\hline $37 \mathrm{R}-3,140-150$ & 697.5 & 7.1 & 1.73 & 34.0 & 34.3 & 1.0 & 15.6 & & 0.7 & & 0.26 \\
\hline $39 \mathrm{R}-3,140-150$ & 716.2 & 7.4 & 1.49 & 18.9 & 18.5 & 1.0 & 10.9 & & 0.2 & & 0.14 \\
\hline $42 \mathrm{R}-3,140-150$ & 744.3 & 7.5 & & 27.8 & 33.1 & 0.8 & 13.0 & & 0.8 & & \\
\hline $45 R-3,140-150$ & 772.7 & 7.5 & 1.60 & 32.9 & 41.0 & 0.8 & 16.2 & & 0.5 & & \\
\hline $48 R-3,140-150$ & 801.4 & 7.6 & & 31.9 & 30.9 & 1.0 & 16.9 & & & & \\
\hline $51 R-3,140-150$ & 829.5 & 7.3 & 0.92 & 28.6 & 44.0 & 0.7 & 15.5 & & 0.0 & & 0.27 \\
\hline $54 \mathrm{R}-3,140-150$ & 858.0 & 7.1 & 1.50 & 26.5 & 45.4 & 0.6 & 14.3 & & 0.5 & & 0.27 \\
\hline $57 \mathrm{R}-3,140-150$ & 886.2 & 7.2 & & 28.9 & 43.3 & 0.7 & 14.9 & & 0.0 & & 0.26 \\
\hline $60 \mathrm{R}-3,140-150$ & 912.0 & 7.5 & & 24.2 & 38.7 & 0.6 & 11.7 & & & & \\
\hline
\end{tabular}

ment of $\mathrm{CaCO}_{3}$, and the required fluorine was probably supplied by diffusion from the overlying seawater (Froelich et al., 1983). The rare occurrence of francolite is consistent with the relatively low organic carbon content and low pore-water phosphate concentrations of sediments at Site 765. Ammonium increases to a maximum concentration of $2 \mathrm{mM}$ at $341 \mathrm{mbsf}$. The ammonium maximum occurs at a greater sediment depth than the phosphate maxima, but two local ammonium maxima correspond to the phosphate maxima (Fig. 2). Ammonium ions can exchange rapidly with cations in the interlayer site of smectite minerals (Rosenfeld, 1979). However, the potential for ammonium exchange by sediments within the ammonium maximum at Site 765 is unclear, because these sediments contain relatively small amounts of smectite compared to sepiolite and palygorskite (Compton and Locker, this volume). Although the pore-water $\mathrm{H}_{2} \mathrm{~S}$ and $\mathrm{Fe}$ were not measured at Site 765 , the occurrence of pyrite within the sulfate-reduction zone suggests that $\mathrm{H}_{2} \mathrm{~S}$ and $\mathrm{Fe}$ are reacting at depth in the sediment to form pyrite (Berner, 1970, 1984). The pyrite is framboidal and occurs as silt-sized nodules composed of inlocking crystals (Pl. 1, Figs. 1 and 2) or, less commonly, as pyritized burrows.

Carbonate alkalinity maxima occur at 23 and 72 mbsf (Fig. 2). This increase in carbonate alkalinity results from the $\mathrm{CO}_{2}$ produced during bacterial degradation of organic matter (Claypool and Kaplan, 1974). The alkalinity increase promotes carbonate precipitation by increasing the degree of carbonate saturation (Compton, 1988b). Dolomite appears to be precipitating currently at depth in the sediment at Site 765 based on the removal of pore-water $\mathrm{Ca}$ and $\mathrm{Mg}$ and an alkalinity maximum at the sediment depths where dolomite was first observed. The degree of saturation of the pore water with respect to dolomite and calcite was calculated using the pore-water data from Table 2 . The degree of saturation can be expressed as the ratio of the actual ion activity product $(I A P)$ to the equilibrium or solubility product $(K)$. The carbonate ion activity was calculated from the $\mathrm{pH}$ and titration alkalinity, and the effect of temperature and pressure on the activity coefficients of $\mathrm{Ca}$ and $\mathrm{Mg}$ was taken into account (Berner, $1971)$. The geothermal gradient $\left(32^{\circ} \mathrm{C} / \mathrm{km}\right)$ was used to estimate temperature, and pressure was estimated from the combined sediment and water depths $(10 \mathrm{~m}=1 \mathrm{~atm})$. The effect of temperature and pressure on the equilibrium solubility products of dolomite and calcite was estimated using the procedures of Langmuir (1971) and Berner (1965), and the molar volume data from Millero (1983). The value of the equilibrium solubility product of near-ideal dolomite was taken as $10^{-17}$ at $25^{\circ} \mathrm{C}$ (Hsü, 1963; Holland et al., 1964; Robie et al., 1978).

The pore water at Site 765 is saturated to 10 times supersaturated with dolomite and saturated to slightly undersaturated with 


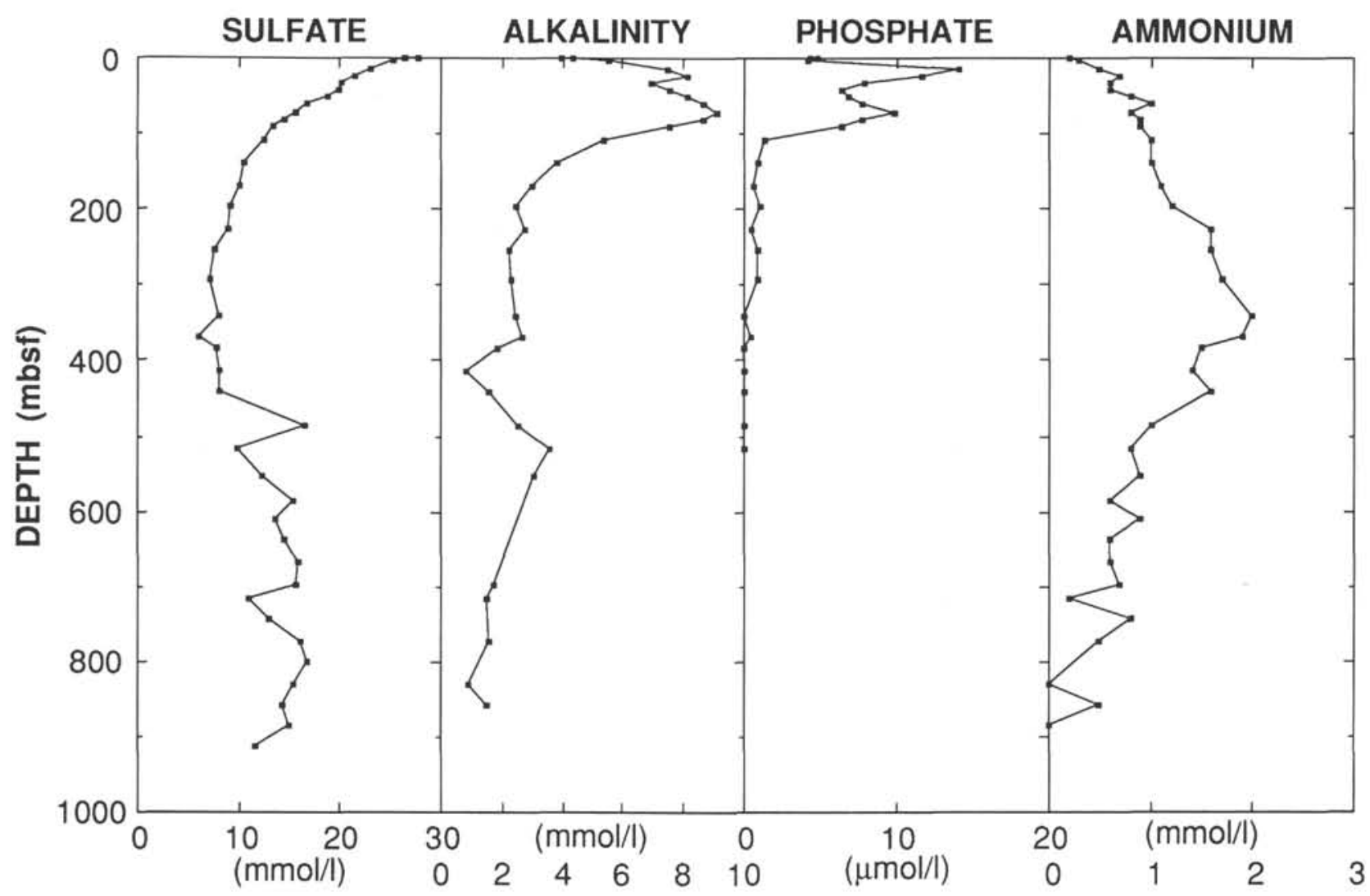

Figure 2. Pore-water sulfate, alkalinity, phosphate, and ammonium as a function of sediment depth at Site 765 .

EARLY DIAGENESIS - SITE 765

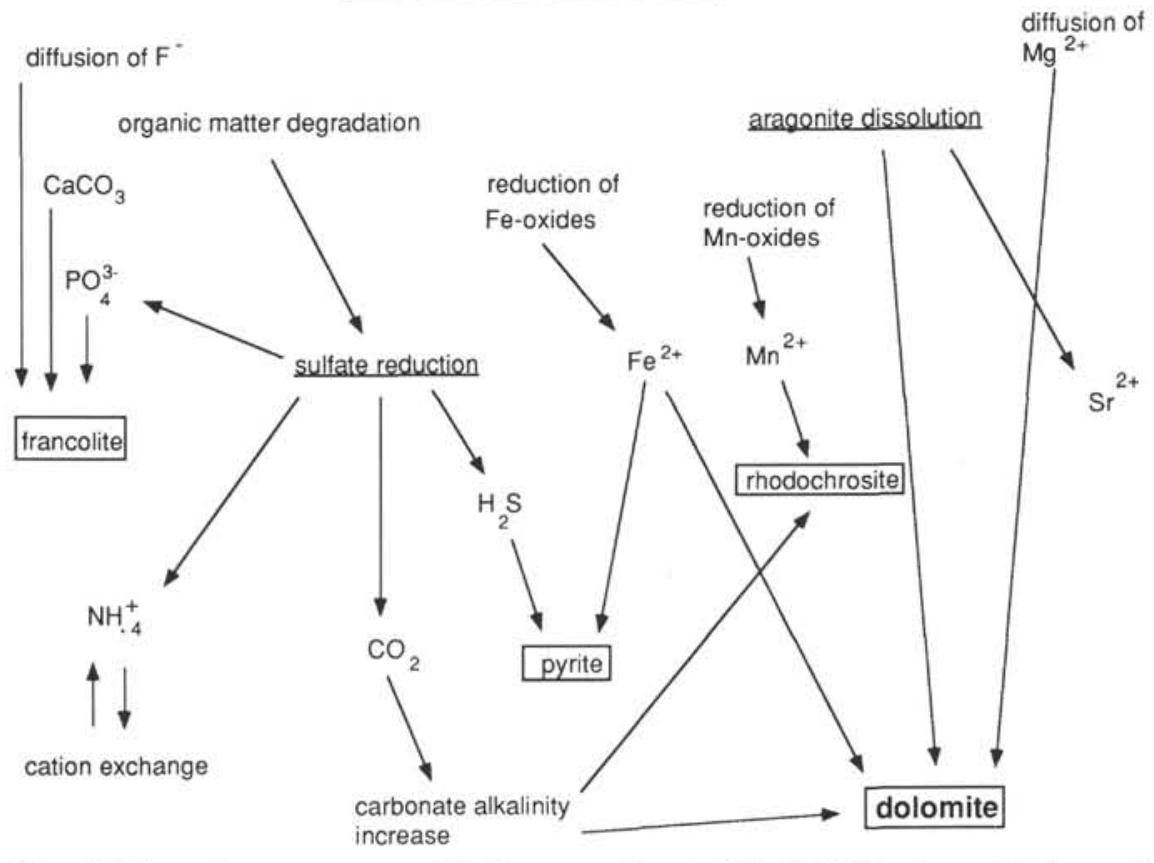

Figure 3. Diagenetic sequence proposed for Neogene sediments at Site 765. Dolomite precipitation results from the degradation of organic matter by sufate-reducing bacteria and the dissolution of aragonite. 
LOG(IAP/K)CALCITE AND LOG(IAP/K)DOLOMITE

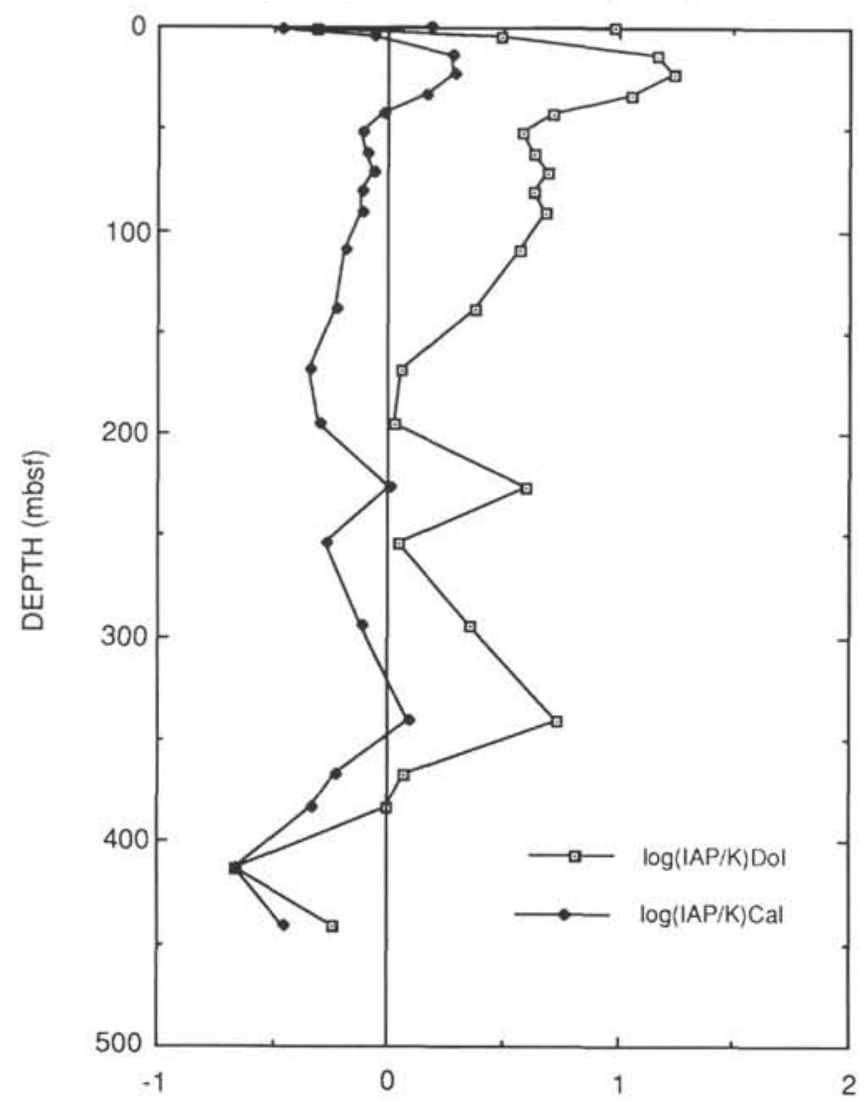

Figure 4. Log of calculated degree of saturation (IAP/K) of dolomite and calcite in pore water as a function of sediment depth at Site 765 (saturation $=0$ ).

calcite (Fig. 4). Changes in the degree of saturation with sediment depth are similar for both dolomite and calcite and reflect changes in the alkalinity and $\mathrm{pH}$. The calculated values are approximate because of the uncertainty in the temperature and pressure dependence of the equilibrium solubility products and difficulties in accurately determining the in-situ $\mathrm{pH}$. The calculated values are probably too high because the titration alkalinity is greater than the carbonate alkalinity and, more significantly, because the measured $\mathrm{pH}$ is probably too high from $\mathrm{CO}_{2}$ degassing (Gieskes, 1973). In addition, these are nonideal dolomites because they contain an average of $7.5 \mathrm{~mol} \%$ excess $\mathrm{Ca}$ (Table 1) and, therefore, should be more soluble than ideal dolomite (e.g., Helgeson et al., 1978). Aragonite is undersaturated at all sediment depths at Site 765 because the solubility of aragonite is approximately 1.5 to 3 times greater than that of calcite, depending on the thermodynamic data used (Woods and Garrels, 1987).

Dolomite is notoriously difficult to precipitate at low temperatures. Several factors that enhance dolomite precipitation at low temperature include (1) high degree of supersaturation (high carbonate alkalinity), (2) high $\mathrm{pH},(3)$ high pore-water $\mathrm{Mg} / \mathrm{Ca}$ ratio, (4) low sulfate concentration, and (5) a metastable carbonate precursor (aragonite or high-Mg calcite). The lowered sulfate concentrations at Site 765 may promote dolomite precipitation because sulfate ion has been shown to inhibit the precipitation of dolomite in laboratory experiments (Baker and Kastner, 1981; Kastner and Baker, 1982). Dolomitization of calcite was found to be inhibited by sulfate at concentrations of $5 \%$ to $7 \%$ of seawater sulfate, but dolomitization of aragonite was inhibited only at sulfate concentrations greater than $50 \%$ of seawater sulfate. In addition, the transformation of aragonite to dolomite was found to be 4 to 6 times faster than calcite in sulfate-free solutions at $150^{\circ} \mathrm{C}$ (Kastner and Baker, 1982). The first occurrence of dolomite at Site 765 corresponds to the sediment depth where sulfate is depleted to below $50 \%$ of its seawater value. Sulfate is further depleted to about $75 \%$ of its seawater value in the sediment interval that contains the most abundant dolomite. The enhancement of dolomitization by an aragonite rather than a calcite precursor may explain the strong association of dolomite and aragonite at Site 765 .

Pore-water $\mathrm{Ca}$ decreases in the uppermost $110 \mathrm{mbsf}$ and then increases with sediment depth (Fig. 5). An initial decrease in $\mathrm{Ca}$, associated with an increase in alkalinity, was commonly observed in rapidly deposited, organic-rich sediments and is a result of carbonate precipitation (Gieskes, 1981). Depletion of Ca at Site 765 may result from the direct precipitation of dolomite,

$$
\mathrm{Ca}^{2+}+\mathrm{Mg}^{2+}+2 \mathrm{HCO}_{3}^{-}=\mathrm{CaMg}\left(\mathrm{CO}_{3}\right)_{2}+2 \mathrm{H}^{+},
$$

or calcite because pore waters are supersaturated with both minerals in the sediment interval of Ca depletion (Fig. 4). The increase of Ca below 110 mbsf corresponds to a decrease in alkalinity and an increased gradient in $\mathrm{Mg}$, suggesting that the carbonate reaction changes from predominantly direct precipitation (Eq. 1) to replacement of precursor aragonite or calcite below $100 \mathrm{mbsf}$,

$$
2 \mathrm{CaCO}_{3}+\mathrm{Mg}^{2+}=\mathrm{CaMg}\left(\mathrm{CO}_{3}\right)_{2}+\mathrm{Ca}^{2+} .
$$

The $\mathrm{Mg}$ concentration decreases gradually from 0 to $100 \mathrm{mbsf}$ and then more rapidly from 100 to $250 \mathrm{mbsf}$ (Fig. 5). The decrease in $\mathrm{Mg}$ results from the precipitation of dolomite as well as the $\mathrm{Mg}$-rich clay minerals sepiolite and palygorskite (Compton and Locker, this volume). The $\mathrm{Mg}$ gradient is slightly greater than the $\mathrm{Ca}$ gradient in the uppermost $100 \mathrm{mbsf}$, which suggests that both the replacement reaction (Eq. 2) and direct precipitation (Eq. 1) are occurring in the uppermost sediment. The replacement reaction is also supported by the strong correlation between the amount of aragonite and dolomite in the sediment (Fig. 1). The pore-water $\mathrm{Mg} / \mathrm{Ca}$ ratio increases rapidly in the uppermost 100 mbsf, which favors the precipitation of dolomite (Eq. 2). The $\mathrm{Mg} / \mathrm{Ca}$ ratio then decreases to an asymptotic value of about 1 , a trend commonly observed in marine sediments undergoing dolomitization and a ratio that is predicted for pore water in thermodynamic equilibrium with dolomite (Robie et al., 1978; Compton, 1988b).

Pore-water $\mathrm{Mn}$ increases rapidly to $73 \mu \mathrm{M}$ in the uppermost $14 \mathrm{mbsf}$ and then decreases to near zero by $100 \mathrm{mbsf}$ (Fig. 5). The $\mathrm{Mn}$ concentration spike probably results from the reduction of $\mathrm{Mn}$ oxides. The reduced $\mathrm{Mn}$ is then available for incorporation into precipitating carbonate. No rhodochrosite $\left(\mathrm{MnCO}_{3}\right)$ was identified positively in the Neogene sediments at Site 765; however, the presence of small amounts of rhodochrosite cannot be ruled out because the most intense rhodochrosite XRD peak coincides with a calcite peak, making it difficult to detect small amounts of rhodochrosite in these calcite-rich sediments. Much of the porewater Mn was probably taken up by dolomite, which contains minor to trace amounts of Mn (Table 1). Similar to $\mathrm{Mn}, \mathrm{Fe}$ was probably derived from the reduction of $\mathrm{Fe}$ oxides and taken up directly from pore water during dolomite and pyrite formation. The amount of $\mathrm{Fe}$ available for carbonate precipitation may have been limited by the removal of $\mathrm{Fe}$ from the precipitation of pyrite, whereas the amount of Mn carbonate may have been limited by the low Mn concentrations at depth in the sediment (Fig. 5).

The availability of reduced $\mathrm{Fe}$ and $\mathrm{Mn}$ for carbonate precipitation in these sediments may be related to the periodic deposition of the turbidite sequences. Each new turbidite event results in the sudden deposition of calcite, aragonite, aluminosilicates, and 


\section{CALCIUM AND MAGNESIUM}

$\mathrm{Mg} / \mathrm{Ca}$

MANGANESE

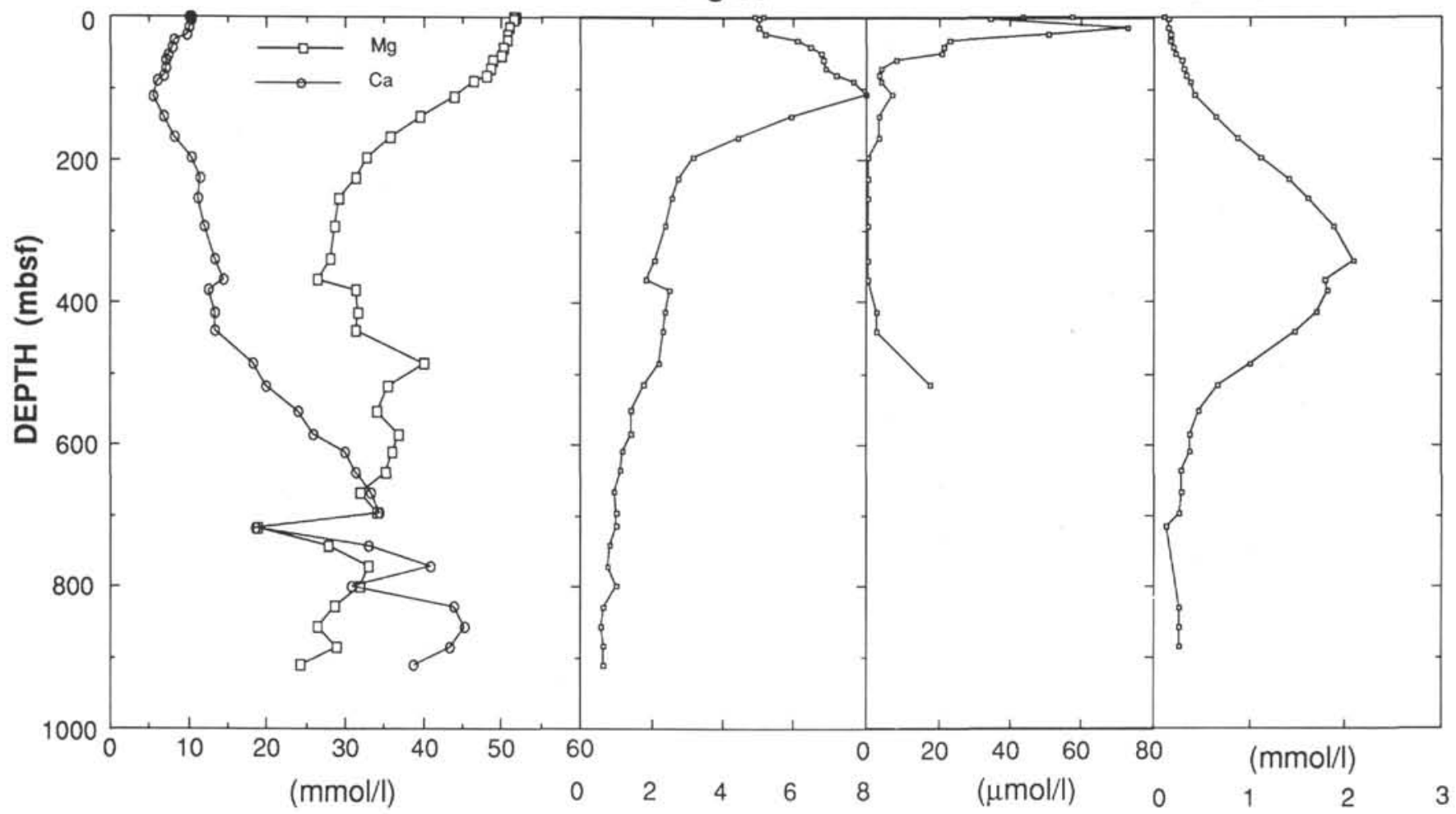

Figure 5. Pore-water calcium, magnesium, $\mathrm{Mg} / \mathrm{Ca}$ ratio, manganese, and strontium as a function of sediment depth at Site 765 .

organic matter derived from the continental margin. The transported organic matter avoids significant degradation by oxygenated bottom waters because of its rapid burial. After burial, the organic matter undergoes degradation by sulfate-reducing bacteria. $\mathrm{Fe}$ and $\mathrm{Mn}$ oxides that had accumulated at the sediment/ seawater interface prior to turbidite deposition were reduced and diffused through the sediment to precipitate as carbonate or sulfide minerals, or they were diffused to the new sediment/seawater interface to precipitate as $\mathrm{Fe}$ and $\mathrm{Mn}$ oxides. Most turbidites appear to have had enough organic carbon to create the reducing conditions to recycle the previously accumulated Fe and Mn oxides. During periods of slow pelagic sedimentation between turbidite deposits, carbonate at the sediment/seawater interface should dissolve and biogenic silica and aluminosilicates should accumulate below the CCD, but the bulk of the redeposited carbonate was removed from undersaturated bottom waters by rapid burial. Calcite and aragonite underwent gradual recrystallization with increasing burial depth, partially lithifying the calcareous turbidites by $200 \mathrm{mbsf}$ and forming chalks by $550 \mathrm{mbsf}$, similar to the carbonate burial diagenesis described at other deepsea sites (e.g., Garrison, 1981). The partial lithification of the sediment below 200 mbsf may have been enhanced by dolomite precipitation. Chalk from below 600 mbsf at Site 765 contains recrystallized calcite (observed in SEM) and a much lower bulk sediment Sr content (Fig. 1; Baker et al., 1982).

Solution of aragonite is shown by the pore-water $\mathrm{Sr}$ profile (Fig. 5). Pore-water Sr rapidly increases with sediment depth to a maximum of $2.1 \mathrm{mM}$ at $341 \mathrm{mbsf}$ and then decreases to $0.3 \mathrm{mM}$ at $668 \mathrm{mbsf}$. The pore-water Sr maximum corresponds to the aragonite-rich sediment interval (Fig. 1). A Sr concentration of $2.1 \mathrm{mM}$ is unusually high for pelagic carbonate sediments and is the result of rapid solution of $\mathrm{Sr}$-rich aragonite and limited uptake of $\mathrm{Sr}$ by the recrystallized carbonate minerals (Baker et al., 1982). Celestite $\left(\mathrm{SrSO}_{4}\right)$ nodules have been reported from pelagic car- bonates where the $\mathrm{Sr}$ concentration is relatively high (Baker and Bloomer, 1988). Celestite was not detected at Site 765. High Sr concentrations do not result in the precipitation of celestite at Site 765 because the $\mathrm{Sr}$ maximum corresponds to the sulfate minimum. Pore waters at Site 765 were calculated as undersaturated to slightly supersaturated with celestite, assuming atmospheric pressure. However, the pressure in these sediments is on the order of $600 \mathrm{atms}$, and the solubility of celestite appears to increase with increasing pressure (North, 1974; Baker and Bloomer, 1988), suggesting that pore waters at Site 765 are undersaturated with respect to celestite.

The rate of aragonite dissolution can be estimated from the average diffusive flux of pore-water $\mathrm{Sr}$, assuming steady-state diagenesis (Berner, 1980). The $\mathrm{Sr}$ content of the aragonite was estimated as on the order of $0.8 \mathrm{wt} \%$, based on the correlation between $\mathrm{Sr}$ and $\mathrm{CaCO}_{3}$ contents of the bulk sediment (Ludden, Gradstein, et al., 1990). The amount of Sr removed from the pore water was assumed to be negligible because the recrystallized calcite and dolomite contain much less $\mathrm{Sr}$ than aragonite. The total average flux of $\mathrm{Sr}$ out of the aragonite-rich sediment interval was

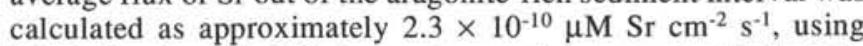
Fick's first law of diffusion and assuming a constant bulk-sediment diffusion coefficient of $4 \times 10^{-6} \mathrm{~cm}^{-2} \mathrm{~s}^{-1}$. Averaging over the aragonite-rich sediment interval from 200 to $450 \mathrm{mbsf}$ and using an average bulk-sediment density of $1.9 \mathrm{~g} \mathrm{~cm}^{-3}$, the $\mathrm{Sr}$ flux requires the solution of roughly $0.3 \mathrm{wt} \%$ aragonite/m.y. The total amount of dissolved aragonite required since deposition to support the current $\mathrm{Sr}$ flux is on the order of the amount of dolomite observed in the sediment interval from 200 to 450 mbsf (2-6 $w t \%)$, suggesting that aragonite was an important precursor to dolomite precipitation.

Total carbonate and diagenetic carbonate minerals are far less abundant below $500 \mathrm{mbsf}$ at Site 765 . Trace to minor amounts of dolomite occur below $440 \mathrm{mbsf}$; rhodochrosite was observed from 
740 to 900 mbsf; and siderite was tentatively identified by XRD from 525 to 631 mbsf. The rhodochrosite occurs as silt-sized, spherical aggregates of intergrown microcrystals. Most of the rhodochrosite has been interpreted to have precipitated in situ (Ludden, Gradstein, et al., 1990). The formation of rhodochrosite is most often associated with the degradation of organic matter in anoxic sediments (Suess, 1979; Pedersen and Price, 1982; Jakobsen and Postma, 1989). Reduction of Mn oxides releases Mn to the pore water, where it can directly precipitate as rhodochrosite in high-carbonate alkalinity pore waters that are supersaturated with respect to rhodochrosite. Rhodochrosite in organic-rich marine sediment from the Baltic Sea was found to contain 10 to $40 \mathrm{~mol}_{\%} \mathrm{CaCO}_{3}$ and 2 to $5 \mathrm{~mol} \% \mathrm{MgCO}_{3}$ (Jakobsen and Postma, 1989). The elemental composition of a single rhodochrosite sample (123-765C-45R-3, 140-150 cm) from $773 \mathrm{mbsf}$ is similar to the composition of rhodochrosites from the Baltic Sea, $\left(\mathrm{Mn}_{0.84} \mathrm{Ca}_{0.11} \mathrm{Mg}_{0.04} \mathrm{Fe}_{0.01}\right) \mathrm{CO}_{3}$. The large negative $\delta^{13} \mathrm{C}$ value of the rhodochrosite (Table 1) suggests that it formed early in the sulfate-reduction zone during decomposition of organic matter (see below). However, the depleted $\delta^{18} \mathrm{O}$ value suggests that the rhodochrosite may have recrystallized at a higher temperature associated with deeper burial depths (Fig. 6). The sediment interval where rhodochrosite occurs also contains pyrite, which is consistent with its origin in sulfate-reducing, anoxic pore waters. The organic carbon content of the sediment is generally low, with the exception of a single measurement of $5 \mathrm{wt} \%$ organic carbon at $774 \mathrm{mbsf}, 1 \mathrm{~m}$ below the analyzed rhodochrosite sample.

\section{Elemental and Isotopic Analyses of the Dolomite}

The elemental and carbon and oxygen isotopic analyses of dolomite samples and one rhodochrosite sample from Site 765 are listed in Table 1. The $\mathrm{Ca}$ and $\mathrm{Mg}$ contents of the bulk dolomite samples are remarkably similar, but the Fe and Mn contents are variable. Calcian dolomites commonly precipitate from solutions that have salinities and $\mathrm{Mg} / \mathrm{Ca}$ ratios that are close to those observed at Site 765 (Morrow, 1982). Oxygen and carbon isotopic values of the dolomite samples range from 2.6 to $5.5 \% \delta^{18} \mathrm{O}$ (PBD) and -0.1 to $6.6 \% \delta^{13} \mathrm{C}$ (PDB), respectively (Fig. 6). Overlapped onto Figure 6 is the generalized pore-water d13C curve observed for organic-rich marine sediments (Claypool and Kaplan, 1974; Irwin et al., 1977; Pisciotto and Mahoney, 1981; Kelts and McKenzie, 1982). The negative $\delta^{13} \mathrm{C}$ shift to about $-20 \% 0$ occurs in the sulfate-reduction zone from the preferential bacterial degradation of light organic carbon. The swing to heavier $\delta^{13} \mathrm{C}$ values occurs during the transition from sulfate reduction to methanogenesis, where isotopically light bicarbonate is preferentially reduced to methane, resulting in a heavier residual porewater bicarbonate. The actual position of the pore-water $\delta^{13} \mathrm{C}$ curve with respect to sediment depth will depend, in part, on the sedimentation rate and the geothermal gradient (e.g., Pisciotto and Mahoney, 1981). Also shown in Figure 6 are the ranges in isotopic compositions reported for Neogene benthic foraminifers (e.g., Miller and Fairbanks, 1985; Vincent and Berger, 1985) and Pleistocene to Holocene marine dolomites (adapted from Hardie, 1987). Organogenic dolomites from the Miocene Monterey Formation are not plotted in Figure 5, but cover a broad range of isotopic compositions from -20 to $20 \% 0 \delta^{13} \mathrm{C}$ and -6 to $6 \% 0 \delta^{18} \mathrm{O}$ (e.g., Garrison et al., 1984).

The large, positive $\delta^{18} \mathrm{O}$ values of the dolomites from Site 765 suggest that the dolomite formed at relatively low temperatures during early burial diagenesis. This is consistent with their occurrence in the uppermost $450 \mathrm{mbsf}$ and a geothermal gradient at Site 765 of $32^{\circ} \mathrm{C} / \mathrm{km}$ (Ludden, Gradstein, et al., 1990). The $\delta^{18} \mathrm{O}$ values do not show a trend to lower values with increasing burial depth. The positive $\delta^{18} \mathrm{C}$ values suggest that most of the carbon in the dolomite was derived from precursor biogenic carbonate (pelagic

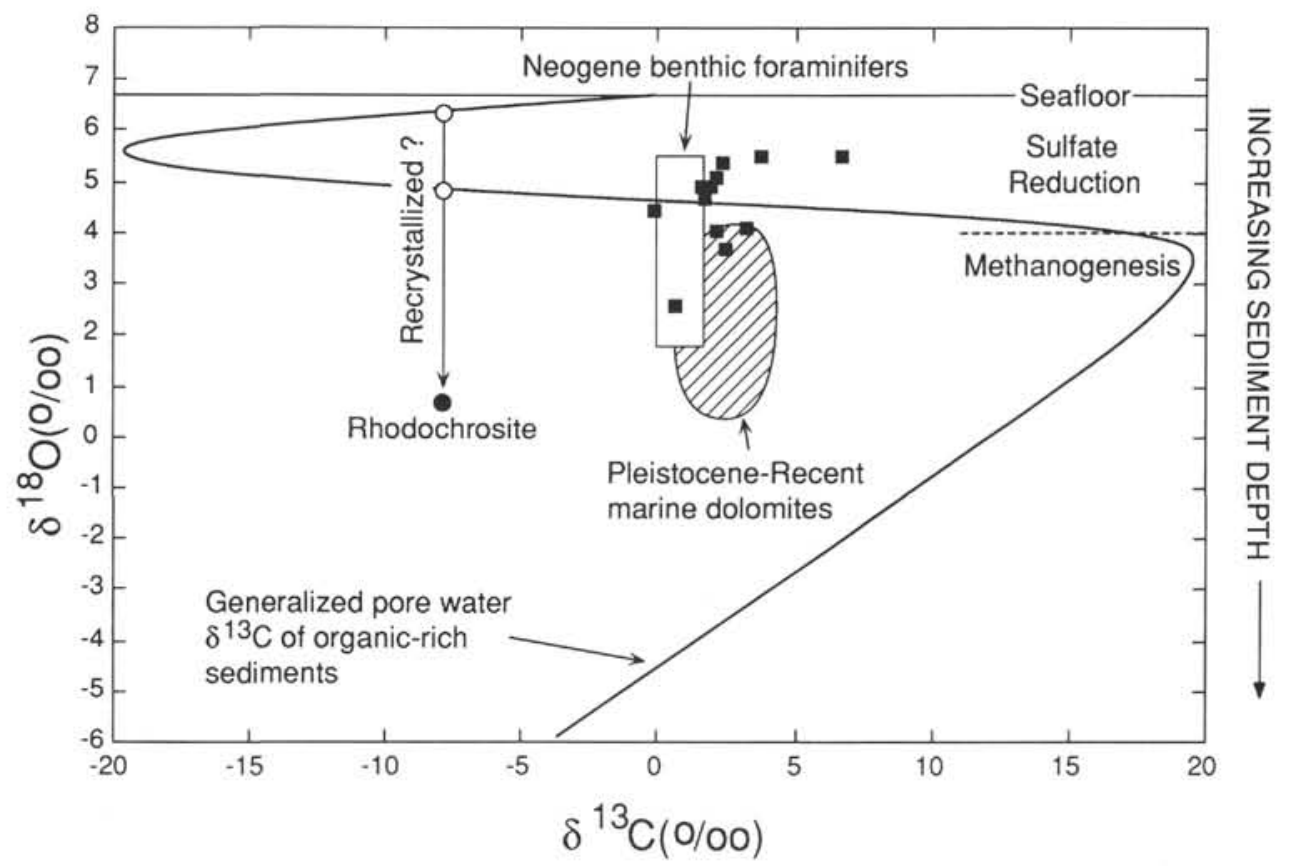

Figure 6. Stable oxygen and carbon isotopic compositions of dolomite samples (filled squares) and one rhodochrosite sample (filled circle) from Site 765 . Solid line represents generalized pore-water $\delta^{13} \mathrm{C}$ of organic-rich sediment from the sediment/seawater interface through the sulfate-reduction and methanogenesis zones (Claypool and Kaplan, 1974). Rectangular area is the range in isotopic values for Neogene benthic foraminifers (e.g., Miller and Fairbanks, 1985; Vincent and Berger, 1985), and the circular area is the range of Pleistocene to Holocene marine dolomites (after Hardie, 1987). Refer to discussion in text. 
calcite and benthic aragonitic (Ludden, Gradstein, et al., 1990). The $\delta^{18} \mathrm{O}$ values do not exhibit a trend to lower values with increasing burial depth. The positive $\delta^{13} \mathrm{C}$ values suggest that most of the carbon in the dolomite was derived from precursor biogenic carbonate (pelagic calcite and benthic aragonitic foraminifers), not from the degradation of organic matter in the sulfate-reduction zone. This is particularly true for the dolomite that occurs in the present sulfate-reduction zone, where the alkalinity maxima occur and where the pore-water bicarbonate is anticipated to have large negative $\delta^{13} \mathrm{C}$ values. Most of the dolomite samples have $\delta^{13} \mathrm{C}$ values that are somewhat heavier than biogenic carbonates, suggesting that some of the carbonate may have been derived from the degradation of organic matter near the boundary between sulfate reduction and methanogenesis. In summary, the isotopic composition of the dolomites suggests that they formed during early burial, predominantly by replacement of precursor aragonite and calcite and that organic matter degradation provided only a minor source of carbonate during dolomite precipitation. This is consistent with the correlation between dolomite and aragonite contents, and the low organic matter content of sediment from Site 765 in comparison to the high organic matter content associated with most organogenic dolomites (e.g., Garrison et al., 1984).

\section{CONCLUSIONS}

The abundance of diagenetic dolomite is surprising when one considers the relatively low organic matter content of the sediment at Site 765. The key factor for explaining the precipitation of dolomite at Site 765 is the abundance of aragonite. The carbon isotopic composition of the dolomite suggests that most of the carbon was derived primarily from precursor biogenic carbonate, not from the degradation of organic matter. Most of the dolomite at Site 765 appears to have formed by replacement of aragonite, based on the Sr mass-balance calculations, the pore-water $\mathrm{Ca}$ and $\mathrm{Mg}$ profiles, and the strong correlation of dolomite and aragonite contents. However, some of the carbonate in the dolomite was probably derived from the degradation of organic matter. Although limited in.amount, organic matter degradation promotes dolomite precipitation at Site 765 because it reduces the sulfateion concentration and increases the carbonate alkalinity. Dolomite probably nucleates in the alkalinity maxima observed in the uppermost sediment, as suggested by the high degree of supersaturation and the first observation of fine-grained dolomite rhombs at 62 mbsf. Once nucleated, dolomite might continue to precipitate as aragonite dissolves. The required $\mathrm{Mg}$ is supplied by diffusion from the overlying seawater. Therefore, organic matter degradation at Site 765 is important because it enhances dolomite nucleation and growth by producing supersaturated pore waters and by significantly depleting sulfate ion for less-inhibited dolomitization of aragonite.

\section{ACKNOWLEDGMENTS}

Financial support is gratefully acknowledged from USSAC. I thank the members of the Leg 123 scientific party, technicians, and crew. T. Greco assisted with the SEM work, J. Breland assisted with the AA analyses, and S. Locker assisted with the figures. T. Bralower and two anonymous reviewers provided useful comments and suggestions. I particularly wish to thank P. Swart for providing isotopic analyses and T. Plank for providing chemical analyses of the dolomite.

\section{REFERENCES}

Baker, P. A., and Bloomer, S. H., 1988. The origin of celestite in deep-sea carbonate sediments. Geochim. Cosmochim. Acta, 52:335-339.
Baker, P. A., and Burns, S. J., 1985. Occurrence and formation of dolomite in organic-rich continental margin sediments. AAPG Bull., 69:1917-1930.

Baker, P. A., and Kastner, M., 1981. Constraints on the formation of sedimentary dolomite. Science, 213:214-216.

Baker, P. A., Gieskes, J. M., and Elderfield, H., 1982. Diagenesis of carbonates in deep-sea sediments-evidence from $\mathrm{Sr} / \mathrm{Ca}$ ratios and interstitial dissolved $\mathrm{Sr}^{2+}$ data. J. Sediment. Petrol. 52:71-82.

Berner, R. A., 1965. Activity coefficients of bicarbonate, carbonate and calcium ions in sea water. Geochim. Cosmochim. Acta, 29:947-965. 1970. Sedimentary pyrite formation. Am. J. Sci., 268:1-23. 1971. Principles of Chemical Sedimentology: New York (McGraw-Hill) 1980. Early Diagenesis: Princeton (Princeton Univ. Press). 1984. Sedimentary pyrite formation: An update. Geochim. Cosmochim. Acta, 48:605-615.

Claypool, G., and Kaplan, I., 1974. The origin and distribution of methane in marine sediments. In Kaplan, I. (Ed.), Natural Gases in Marine Sediments: New York (Plenum), 99-139.

Compton, J. S., 1988a. Sediment composition and precipitation of dolomite and pyrite in the Neogene Monterey and Sisquoc Formations, Santa Maria basin area, California. In Shukla, V. and Bakef, P. A. (Eds.), Sedimentology and Geochemistry of Dolostones. Soc. Econ. Paleontol. Mineral. Spec. Publ., 43:53-64.

1988b. Degree of supersaturation and precipitation of organogenic dolomite. Geology, 16:318-321.

Compton, J. S., and Seiver, R., 1986. Diffusion and mass balance of $\mathrm{Mg}$ during early dolomite formation, Monterey Formation. Geochim. Cosmochim. Acta, 50:125-135.

Cooks, H. E., Zemmels, I., and Matti, J. C., 1974. X-ray mineralogy data, Eastern Indian Ocean - Leg 27, Deep Sea Drilling Project. In Veevers, J. J., Heirtzler, J. R., et al., Init. Repts. DSDP, 27: Washington (U.S. Govt. Printing Office), 535-545.

Devol, A. H., Anderson, J. J., et al., 1984. A model for coupled sulfate reduction and methane oxidation in the sediments of Saanich Inlet. Geochim. Cosmochim. Acta, 48:993-1004.

Dix, G. R., and Mullins, H. T., 1987. Shallow, subsurface growth and burial alteration of middle Devonian calcite concentrations. J. Sediment. Petrol., 57:140-152.

Essene, E. J., 1983. Solid solutions and solvi among metamorphic carbonates with applications to geologic thermobarometry. In Reeder, R. J. (Ed.), Rev. Mineral., Carbonates: Mineral.D Chem., 11:77-96.

Froelich, P. N., Kim, K. H., Jahnke, R., Burnett, W. C., Soutar, A., and Deakin, M., 1983. Pore water fluoride in Peru continental margin sediments: uptake from seawater. Geochim. Cosmochim. Acta, 47:1605-1612

Garrison, R. E., 1981. Diagenesis of oceanic carbonate sediments: A review of the DSDP perspective. In Warme, J. E., Douglas, R. G., and Winterer, E. L. (Eds.), The Deep Sea Drilling Project: A Decade of Progress. Soc. Econ. Paleontol. Mineral. Spec. Publ., 32:181-207.

Garrison, R. E., Kastner, M., and Zenger, D. H. (Eds.), 1984. Dolomites of the Monterey Formation and other organic-rich units. Soc. Econ. Paleontol. Mineral. Pac. Sect., 41:1-215.

Gieskes, J. M., 1973. Interstitial water studies; Leg 15, alkalinity, pH, $\mathrm{Mg}, \mathrm{Ca}, \mathrm{Si}, \mathrm{PO}_{4}$ and $\mathrm{NH}_{4}$, In Edgar, N. T., Saunders, J. B., et al., Init. Repts. DSDP, 15: Washington (U.S. Govt. Printing Office), 813-830. 1981. Deep-sea drilling interstitial water studies: Implications for chemical alteration of the oceanic crust, Layers I and II. In Warme, J. E., Douglas, R. G., and Winterer, E. L. (Eds.), The Deep Sea Drilling Project: A Decade of Progress. Soc. Econ. Paleontol. Mineral. Spec. Publ., 32:149-167.

1983. The chemistry of interstitial waters of deep-sea sediments: interpretation of Deep-Sea Drilling data, In Riley, J. P., and R. Chester (Eds.), Chemical Oceanography (Vol. 8): London (Academic Press), 222-269.

Ludden, J. N., Gradstein, F. M., et al., 1990. Proc. ODP, Init. Repts., 123: College Station, TX (Ocean Drilling Program).

Hardie, L. A., 1987. Perspectives: Dolomitization: A critical view of some current views. J. Sediment. Petrol., 57:166-183.

Hein, J. R., and Koski, R. A., 1987. Bacterially mediated diagenetic origin for chert-hosted manganese deposits in the Franciscan Complex, California Coast Ranges. Geology, 15:722-726. 
Helgeson, H. C., Delany, J. M., Nesbitt, H. W., and Bird, K. D., 1978. Summary and critique of the thermodynamic properties of rock-forming minerals. Am. J. Sci., 278(A):1-229.

Holland, H. D., Kirsipu, T. V., Huebner, J. S., and Oxburgh, U. M., 1964. On some aspects of the chemical evolution of cave waters. J. Geol., 72:36-67.

Hsü, K. J., 1963. Solubility of dolomite and composition of Florida ground waters. J. Hydrol., 1:288-310.

Irwin, H., Curtis, C., and Coleman, M., 1977. Isotopic evidence for source of diagenetic carbonates formed during burial of organic rich sediments. Nature, 269:209-213.

Jackson, M. L., 1969. Soil Chemical Analysis-Advanced Course (2nd ed.): Madison (Published by the author).

Jakobsen, R., and Postma, D., 1989. Formation and solid solution behavior of Ca-rhodochrosites in marine muds of the Baltic deeps. Geochim. Cosmochim. Acta, 53:2639-2648.

Kastner, M., and Baker, P. A., 1982. A new insight into the origin of sedimentary dolomite. Yearbook of Science and Technology: New York (McGraw-Hill).

Kastner, M., Hollander, D., and Garrison, R., 1984. The association of dolomitite-phosphorite-chert: causes and possible diagenetic sequences. In Garrison, R. E., Kastner, R. E., and Zenger, D. H. (Eds.), Dolomites of the Monterey Formation and Other Organic-Rich Units. Pac. Sect., Soc. Econ. Paleontol. Mineral. Spec. Publ., 41:75-86.

Kelts, K. R., and McKenzie, J. A., 1982. Diagenetic dolomite formation in Quaternary anoxic diatomaceous muds of Deep Sea Drilling Project Leg 64, Gulf of California. In Curray, J. R., Moore, D., et al., Init. Repts. DSDP, 64: Washington (U.S. Govt. Printing Office), 553-569.

Langmuir, D. L., 1971. The geochemistry of some carbonate ground waters in central Pennsylvania. Geochim. Cosmochim. Acta, 35:1023-1045.

Lumsden, D. N., 1988. Characteristics of deep-marine dolomite. J. Sediment. Petrol., 58:1023-1031.

Miller, K. G., and Fairbanks, R. G., 1985. Oligocene to Miocene carbon isotope cycles and abyssal circulation changes. In Sundquist, E. T., and Broecker, W. S. (Eds.), The Carbon Cycle and Atmospheric $\mathrm{CO}_{2}$ : Natural Variations Archean to Present. Geophys. Mongr. Ser., 32:469-486.
Millero, F. J., 1983. Influence of pressure on chemical processes in the sea. In Riley, J. P., and Chester, R. (Eds.), Chemical Oceanography (Vol. 8): New York (Academic Press), 2-88.

Morrow, D. W., 1982. Dolomitization models and ancient dolostones. Geol. Assoc. Can., 2:95-107.

North, N. A., 1974. Pressure dependence of $\mathrm{SrSO}_{4}$ solubility. Geochim. Cosmochim. Acta, 38:1075-1081.

Pedersen, T. F., and Price, N. B., 1982. The geochemistry of manganese carbonate in Panama Basin sediments. Geochim. Cosmochim. Acta, 46:59-68.

Pisciotto, K. A., and Mahoney, J. J., 1981. Isotopic survey of diagenetic carbonates, Deep Sea Drilling Project Leg 63. In Yeats, R., Haq, B., et al., Init. Repts. DSDP, 63: Washington (U.S. Govt. Printing Office), 595-609.

Robie, R. A., Hemingway, B. S., and Fisher, J. R., 1978. Thermodynamic properties of minerals and related substances at $298.15 \mathrm{~K}$ and 1 bar pressure and at higher temperatures. U.S. Geol. Surv. Bull., 1452.

Rosenfeld, J. K., 1979. Ammonium adsorption in nearshore anoxic sediments. Limnol. Oceanogr., 24:356-364.

Suess, E., 1979. Mineral phases formed in anoxic sediments by microbial decomposition of organic matter. Geochim. Cosmochim. Acta, 43:339-352.

Veevers, J. J., Heirtzler, J. R., et al., 1974. Init. Repts. DSDP, 27 : Washington (U.S. Govt. Printing Office).

Vincent, E., and Berger, W. H., 1985. Carbon dioxide and polar cooling in the Miocene: the Monterey hypothesis. In Sundquist, E. T., and Broecker, W. S. (Eds.), The Carbon Cycle and Atmospheric $\mathrm{CO}_{2}$ : Natural Variations Archean to Present. Geophys. Monogr., 32:455468.

Woods, T. L., and Garrels, R. M., 1987. Thermodynamic Values at Low Temperature for Natural Inorganic Materials: An Uncritical Summary: New York (Oxford University Press).

Date of initial receipt: 9 July 1990

Date of acceptance: 16 November 1990

Ms 123B-165 


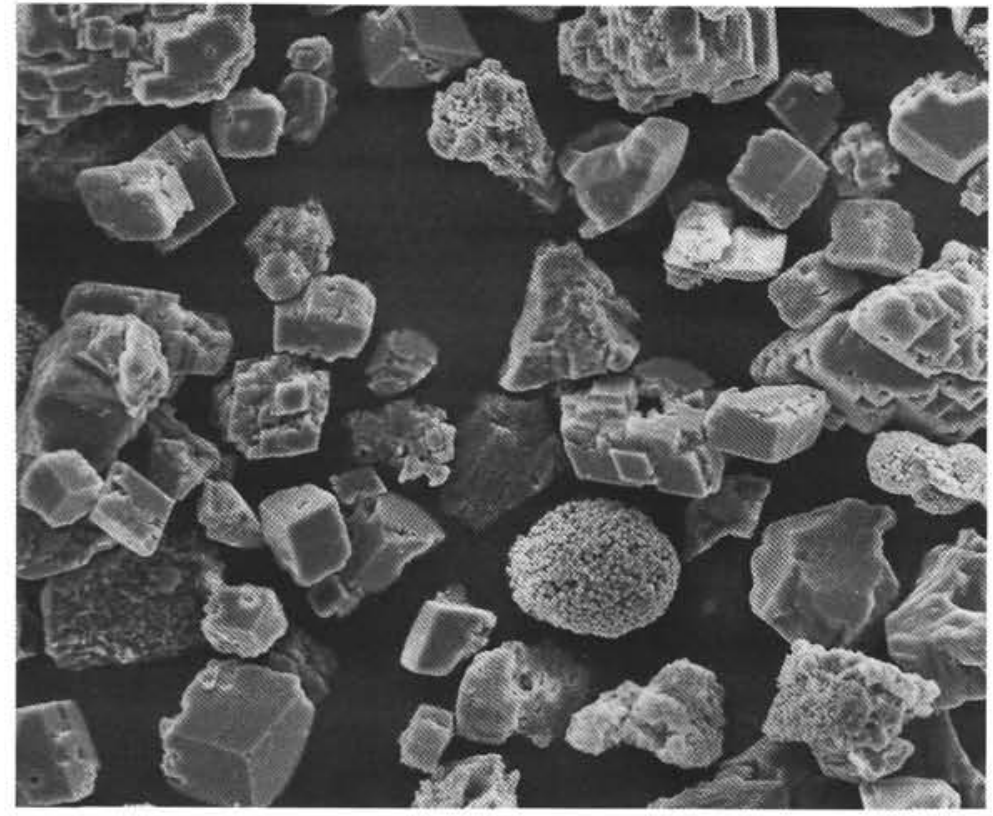

1

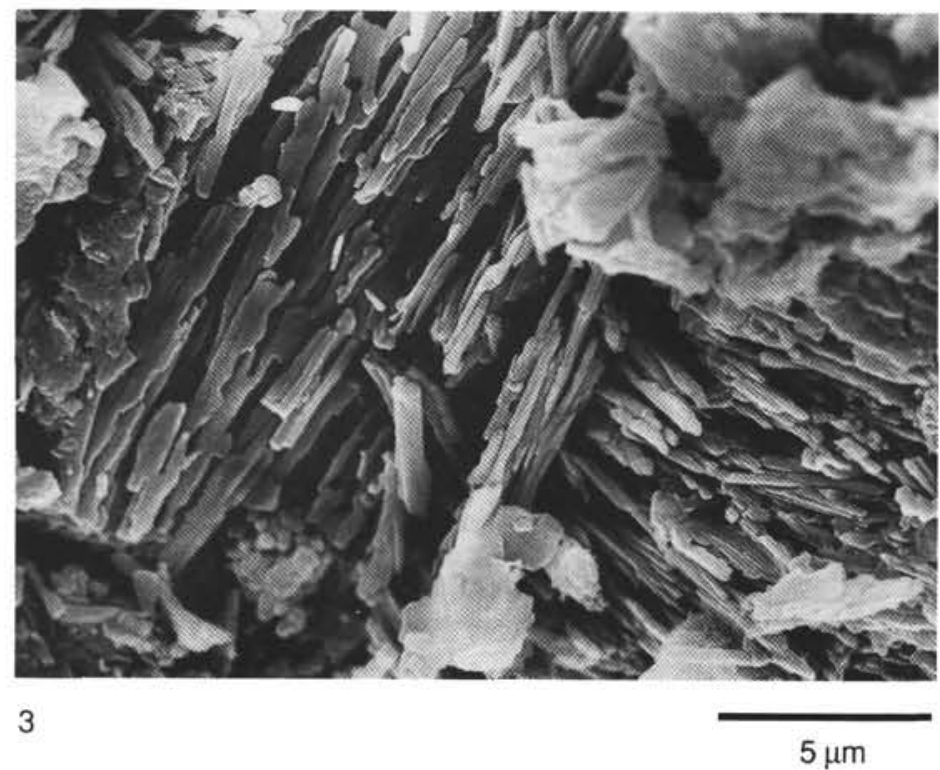

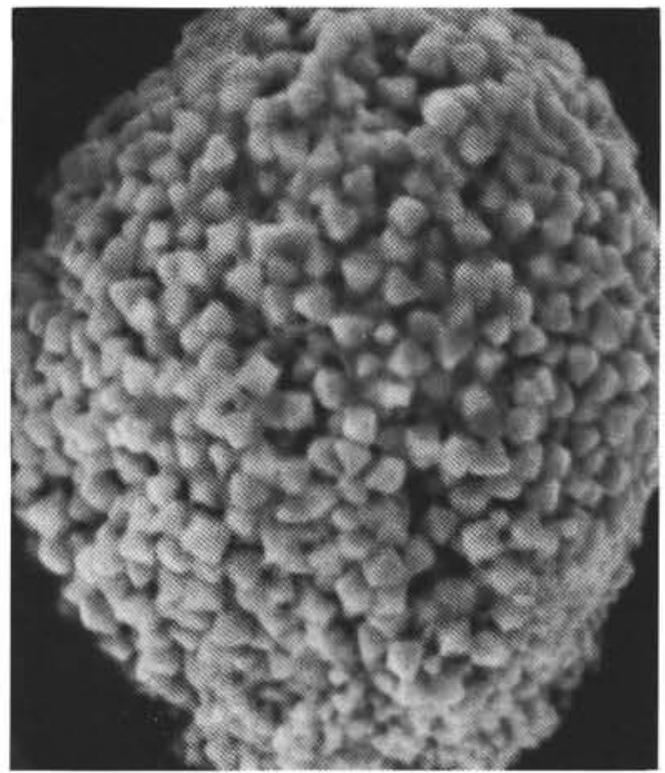

2

$10 \mu \mathrm{m}$

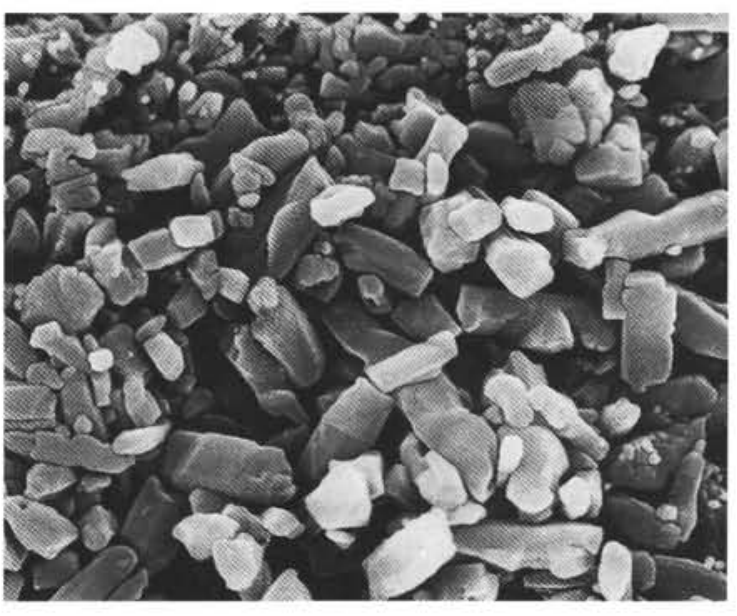

4

Plate 1. SEM photomicrographs of middle Miocene sediment from Site 765.1 . Sample $123-765 \mathrm{C}-10 \mathrm{R}-3,140-150 \mathrm{~cm}$. Processed bulk sediment that contains single and clustered dolomite rhombs, pyrite framboids, and detrital quartz grains (scale bar $=50 \mu \mathrm{m}$ ). The dolomite rhombs are slightly etched from treatment with a sodium acetate-acetic acid buffer at $\mathrm{pH} 5$ that was used to remove calcite and aragonite from the sample. 2. Close-up of pyrite framboid in lower-center of previous photomicrograph that shows intergrown pyrite crystals (scale bar $=10 \mu \mathrm{m}$ ). 3. Sample 123-765C-5R-4, 39-42 cm. Elongate crystals interpreted to be corroded aragonite crystals (scale bar $=5 \mu \mathrm{m}) .4$. Sample 123-765B-38X-1, $44-48 \mathrm{~cm}$. Blocky, recrystallized calcite crystals $(\mathrm{scale}$ bar $=5 \mu \mathrm{m})$. 


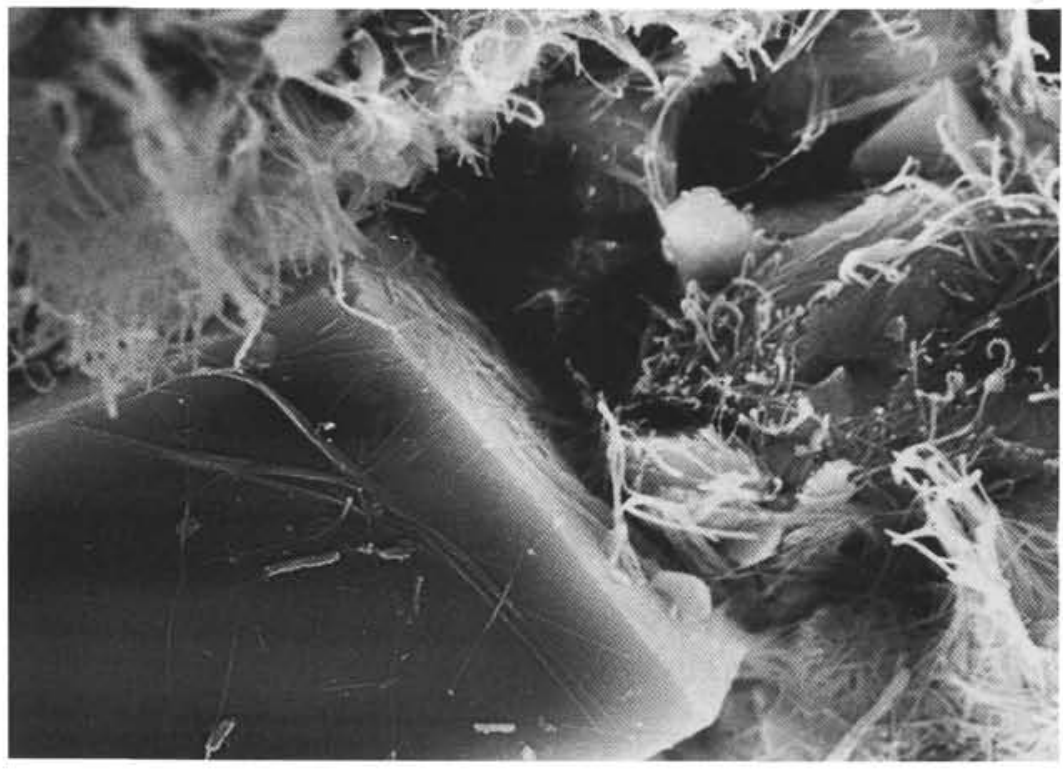

1

$5 \mu \mathrm{m}$

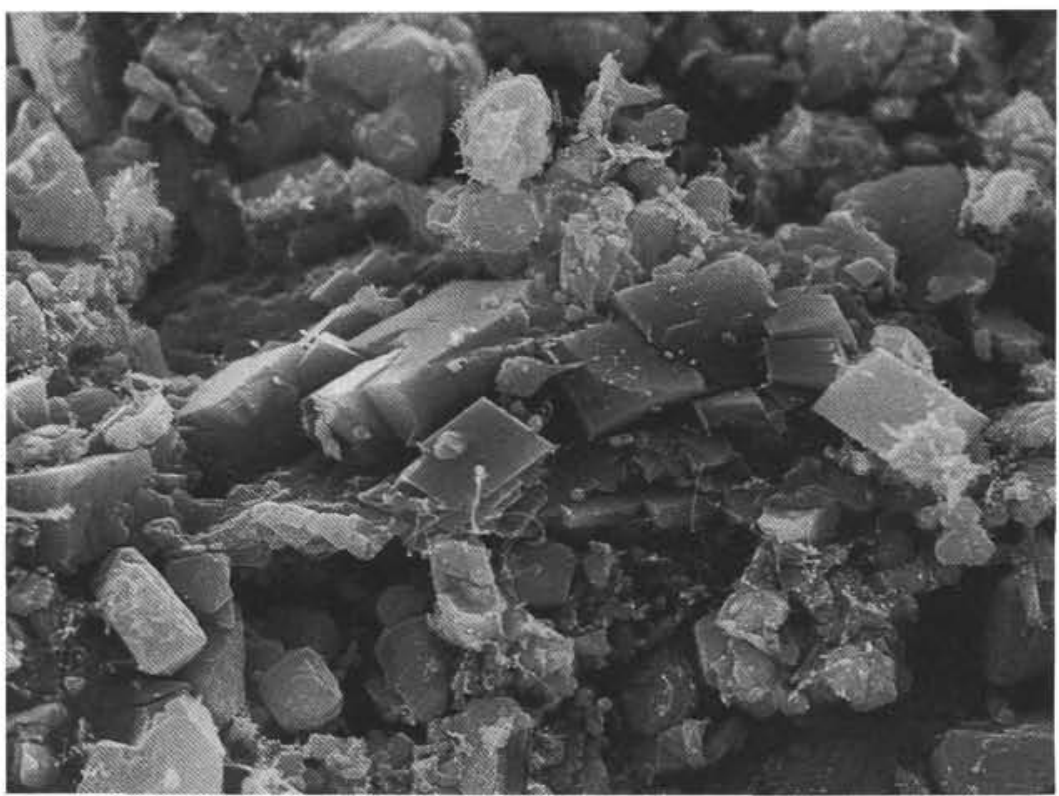

$10 \mu \mathrm{m}$

Plate 2. SEM photomicrographs of fibrous clay minerals associated with dolomite. 1. Sample 123-765C-4R-3, 140-150 cm (middle Miocene). Single, euhedral dolomite rhomb with fibrous palygorskite growing on crystal faces (scale bar $=5 \mu \mathrm{m}$ ). 2. Sample 123-765B-27X-2, 145-150 cm (upper Miocene). Dolomite rhomb in bulk sediment containing sepiolite and palygorskite clay minerals (scale bar $=10 \mu \mathrm{m}$ ). 3. Sample 123-765B-39X-1, 86-91 cm (middle Miocene). Cluster of euhedral dolomite crystals (scale bar $=10 \mu \mathrm{m}$ ). 